\title{
EFFECTIVENESS OF TWO-DIMENSIONAL ANIMATION TECHNIQUE IN ENHANCING STUDENTS' MOTIVATION IN QUANTITATIVE ECONOMICS CONCEPTS
}

\author{
Jovita. C. Ejimonye ${ }^{1}$, Joseph C. Onuoha ${ }^{1}$, Christian S. Ugwuanyi ${ }^{2,3}$, Njideka D. \\ Eneogu $^{1 *}$, Benedict E. Ugwuanyi ${ }^{1}$ and Sylvester N. Ogbuehu ${ }^{1}$ \\ ${ }^{1}$ Department of Social Science Education, Faculty of Education \\ University of Nigeria, Nsukka \\ ${ }^{2}$ Postdoctoral fellow, School of Education Studies, Faculty of Education, \\ University of the Free State, Bloemfontein, 9300, South Africa \\ ${ }^{3}$ Department of Science Education, Faculty of Education \\ University of Nigeria, Nsukka \\ *njideka.eneogu@unn.edu.ng, ${ }^{2}$ ugwuanyics@ufs.ac.za
}

\begin{abstract}
The study investigated the effectiveness of Two-Dimensional Animation Technique in enhancing students' Motivation in Quantitative concepts of Economics. The design adopted for the study was Quasi-experimental nonequivalent pre-test, post-test control group design with a sample size of 162 SS II Economics students made up of 80 males and 82 females drawn from four coeducational secondary schools in Enugu metropolis, Enugu State. Purposive sampling was used to select the four co-educational secondary schools while simple random sampling was used to select the four intact classes from each of the four (4) Schools. Students Motivation in Quantitative Economics Learning scale (SMQELS) was used for data collection. The instrument was face validated and tested for reliability. The SMQELS was subjected to factor analysis and 17 items out of the 20 items survived. A reliability co-efficient of 0.80 was obtained using Cronbach Alpha. The temporal stability index of the instrument was found to be 0.87 using Pearson Product Moment Correlation. Data collected were analysed using mean and standard deviation to answer the research question while ANCOVA was used in testing the null hypothesis at 0.05 level of significance. The result showed that students taught quantitative concepts of Economics with two- dimensional animation technique had significantly higher post-test mean motivation score than those exposed to conventional method. Thus, 2D animation technique proved to be significantly effective in enhancing students' motivation in quantitative contents of economics. It was recommended among others that two-dimensional animation technique should be used in teaching economics in secondary schools.
\end{abstract}

Keywords - Effectiveness, Two-Dimensional Animation Technique, Students' Motivation, Quantitative Economics Concepts

\section{INTRODUCTION}

Received: October 20, 2019

Reviewed: December 30, 2019

Accepted: January 14, 2020

* Corresponding Author

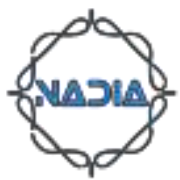


Poor achievement of Economics students in both internal and external examinations has become a source of worry to economics educators and parents at large. The evidence of this poor achievement in Economics is seen in WASSE Chief Examiner's Report of [16] which identified that the students' weaknesses are: poor graphical representations to economic analysis and simple calculations, use of wrong terminologies, failure to expatiate points, among others. In addition, from the overall WAEC statistical report of the performance of Economics students in 2013, 2014 and 2015 in Nigeria, the percentage of Economics students that scored credit and above in 2013 is 46.17\%, 2014 is $26.65 \%$ and 2015 is $20.02 \%$. While the percentage of Economics students that scored lower credit to fail level in 2013 is $51.72 \%, 2014$ is $71.44 \%$ and 2015 is $77.80 \%$. In other words, the trend is not different in Enugu State. This implies that poor achievement of Economics students is increasing annually in spite of the instructional techniques used by the Economics teachers.

This poor achievement of students in economics can be attributed to so many factors. Many students are afraid of Economics because they have not mastered the quantitative aspects and therefore dodge quantitative questions [7-9]. In collaboration with this, [10] found that poor background of students in Mathematics made them to be afraid of quantitative Economics concepts. Students' acquisition of quantitative skills is very important to enhance their achievement in Economics. Economics students who are not knowledgeable in quantitative Economics concepts may not be capable of dealing with economic activities in the society which are key to the survival of any country.

Students are underperforming due to the inefficiency of teachers who may not have adequate knowledge of the subject and innovative ways to present Economics lessons to students [11]. Also, this teacher ineffectiveness could be as a result of inappropriate instructional technique in teaching quantitative Economics concepts. Choice of instructional technique can determine students' academic achievement. Hence, whether the decline in achievement is attributed to the instructional techniques used by the Economics teachers is what this study determined. However, quantitative Economics concepts need the use of innovative instructional techniques that are participatory and motivating for easy transfer of knowledge. Since the invention of computer devices, technologically innovative techniques emerged to alleviate some of the problems of lecture instructional technique but some teachers are ineffective in using them [12]. Such innovative techniques include PowerPoint technique, 2D animation technique, multimedia technique, video conferencing technique, among others.

Two-Dimensional Animation technique is a type of technique which could facilitate learning in an attractive way by engaging the students during teaching and learning process. It is the art of creating movement in a two-dimensional space [13]. Operationally, two-dimensional animation is a design that deals with the movement of inanimate object, diagram or image in an $\mathrm{x}$ and $\mathrm{y}$ environment for the purpose of transferring knowledge to the learners. 2D animation is the art of creating movement in a two-dimensional space. 2D animation is based on $\mathrm{x}$-axis and y-axis and the justification of 2D animation in this study is that, it is suitable for graphical presentations. 2D animation is more like cartoon and parents use it to educate their children at home. Due to the rapid growth of computer hardware and software technologies, computer - aided drawing, such as $2 \mathrm{D}$ and 3D packages, are highly available to students and educational institutes to assist graphical learning and teaching [14]. Secondary school students always play with computer devices like phones and cartoon films. According to [14], it is an important issue to provide computer devices with appropriate pedagogy to facilitate students' graphical learning. Based on this, computer software like 2D animation could be helpful for effective teaching and learning of quantitative Economics concepts. Two-dimensional animation (2D) technique has a wider opportunity over other instructional techniques because of its participatory nature and persistence of vision during the learning process which serves as sources of motivation to the students. 
Motivation awakens and directs students' minds in teaching and learning. Motivation is at the centre in academic achievement of students [15]. Motivation in this study is a force of attraction that arouses students' interest to the subject matter presented by the instructor. It could help students to develop interest on how to learn and acquire necessary skills and strategy in quantitative Economics concepts. Motivation cannot come on its own, something must trigger it which is very important in this study. There must be something that will bring up the mind of any student to understand the concept presented to him/her during the teaching and learning process. Teaching techniques contribute a lot to students' motivation. The type of technique used by the teacher in the class will determine whether the students will be active in the class or not. Current views of learning underline that students' motivation is a crucial factor in successful learning and achievement $[16,17]$. The type of Motivation this study investigated is academic motivation and according to [18] motivation in learning is referred to academic motivation. Motivation is also regarded as a psychological construct that triggers and sustains persistence and effort among individuals [19]. Motivation is the urge to do something or to undertake and accomplish an activity [20]. Motivation has been found to support student engagement and enhance the attainment of learning outcomes [21]. Motivated students devote effort to performing learning tasks, persist when they encounter problems, and regulate their learning [22].

Studies have shown that the use of $2 \mathrm{D}$ animation technique improved the motivation of foreign students. A good number of students have progressive understanding of the biology concepts when computer animation instructional package was used for progressive learning of biology after being taught for three progressive years and the students testified that the package motivated them during the study [23]. Students taught with animated instructional resource did better than those taught with chalk method [24]. Learning with integrated animations significantly increased the students' motivation for science and technology learning of secondary students [25]. [26] Revealed that simulation and animations, when employed in the learning process were efficacious in motivating students in classroom teaching section, Theological Mathematics section and Theological science. [27] Indicated that students who studied with animation pedagogy movies developed greater motivation to learn science. None of these studies use Nigerian sample as participants and that necessitated this study. Thus, the researchers hypothesized that 2D animation technique will not have significant effect in enhancing students' motivation in quantitative contents of economics.

\section{METHODS}

\subsection{ETHICAL CONSIDERATIONS}

Research Ethics Committee of the Faculty of Education, University of Nigeria approved this study. The researchers strictly followed the ethical standard specifications of the American Psychological Association. Students who participated in this study provided informed assent.

\subsection{DESIGN OF THE STUDY}

Pre-test-post-test control group quasi experimental design was adopted by the researchers for the study.

\subsection{PARTICIPANTS}

A total of 162 (80 males and 82 females) in Enugu Metropolis, Enugu State, Nigeria were used as participants. Accuracy of the sample size was ensured using G-Power, version 3.1 which gave 0.79 . 


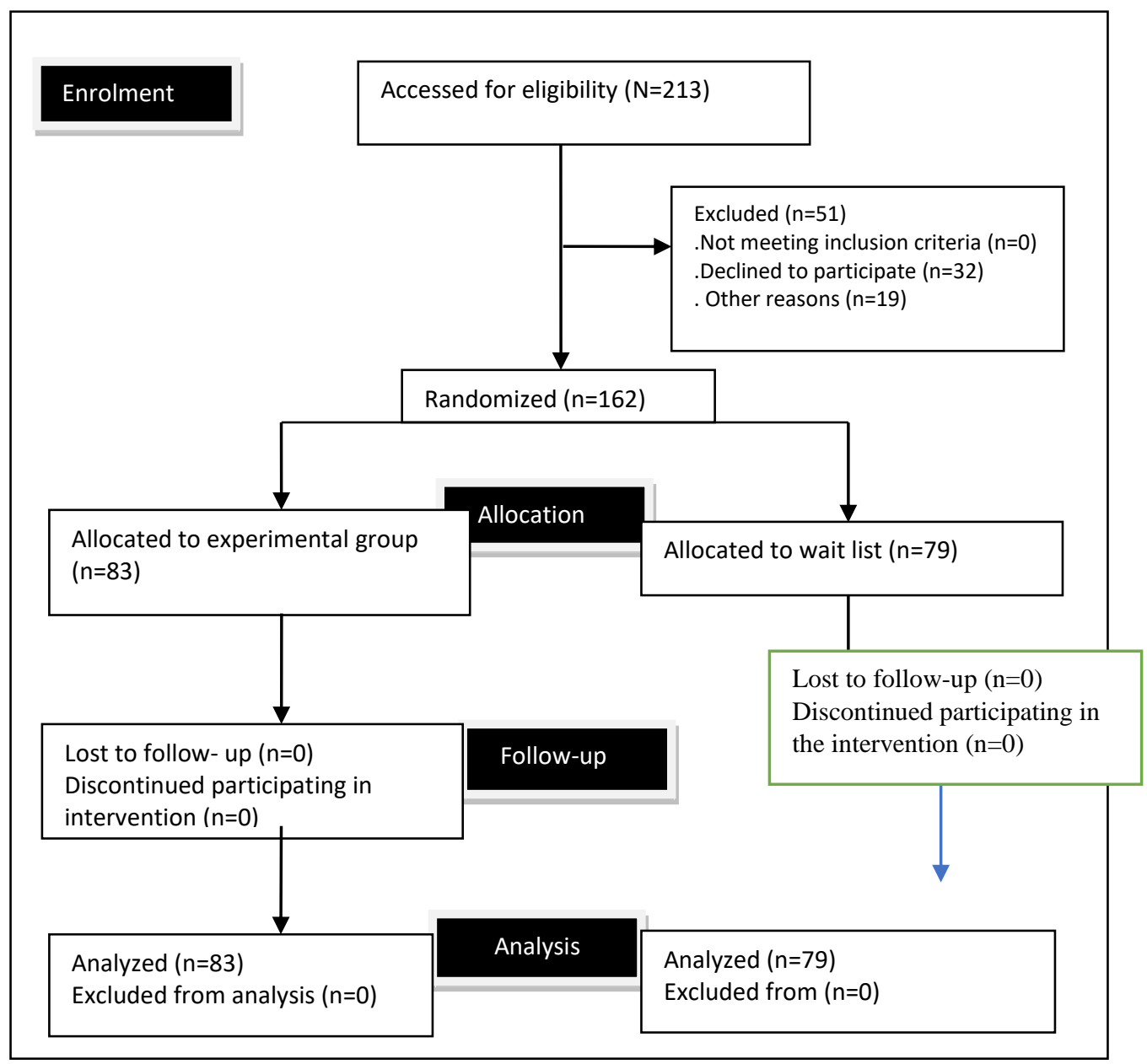

Fig. 1 Flow Diagram for Participants Allocation

\subsection{INSTRUMENT FOR DATA COLLECTION}

The second instrument was the Students Motivation in Quantitative Economics Learning Scale (SMQELS). This instrument was adapted and modified from the motivational regulation scale developed by Miller, Greene, Montalvo, Ravindran and Nichols (1996). The changes made in the original instrument are as follows: the students were tested on how they like or dislike mathematical concepts related to Economics which is not in the original instrument and whether the instructional technique used by the teacher is a factor behind their performance. The objective of this scale was to access students' learning desire and the scale was based on self-determination theory. The scale consisted of 20 items and four dimensions (intrinsic regulations, identified regulations, introject regulations and external regulations). The students showed the level in which they concur with each response option on a five-point scale (Not at all 1 point; very little 2 points; a moderate 3 points; quite a lot 4 points and very true 5 points). Lesson plan for both control and experimental group were prepared and used for the study.

Two-dimensional animation technique movies were designed and developed by the researcher using software like Powtoon, Microsoft word and Microsoft PowerPoint. The design was made by creating storyboards that explain the quantitative Economics concepts with characters. 
Students Motivation in Quantitative Economics Learning Scale (SMQELS) was subjected to both face and construct validation. The face validation of the instrument was done by five experts, two from Measurement and Evaluation, one expert from the Department of Economics and two experts from Educational Technology for the 2D animation design. The experts were requested to check the appropriateness of the instruments in terms of wordings, language expressions in constructing the instrument for the targeted group (SS 2 Economics Students). The corrections made by five experts were used to modify the final copy of the instrument. The construct validation was done by subjecting copies of the instrument to factor analysis using minimum factor loading of 3.00. After factor analysis, 17 items out of the initial 20 items of the instrument survived and were used for the analysis. An internal consistency reliability coefficient of 0.80 was obtained for the items of the instrument using Cronbach Alpha method. The temporal stability of the instrument was estimated using Pearson product moment correlation after the administration of the instruments in two different occasions at two weeks interval. The temporal stability index of 0.87 was obtained for students' motivation scale.

\subsection{PROCEDURE}

The following procedure were used to carry out the quasi-experimental study. Firstly, the researcher met the principals of the schools involved in the study area and sought their permission and co-operation to enable her to incorporate her research programme into the school programme for the term to avoid interrupting the school time table. Through the help of the principals, the researcher contacted the SS 2 Economic teachers in the schools involved. The researcher introduced herself to them and discussed with them the skills involved in using two-dimensional animation technique and what it entails. The researcher trained the teachers on how to use two-dimensional technique in the classroom setting in each of the sampled schools and at their convenient time. The training session lasted for four days for the experimental group. Each day was devoted to training the teachers in each of the schools since all of them cannot come together.

During the training session, the four Economics teachers for the experimental group and control group who were the research assistants were given the lesson plan already prepared for the study. The researcher explained in details to them how to use twodimensional animation technique during teaching and learning processes. The researcher also instructed them on how to use the video during teaching and learning process. The researcher instructed the assistants on the importance of pause during the period the video will be displayed to carry all the students along. The researcher also trained the teachers on how to apply student-teacher interaction when the video will be paused.

Before the experiment commences, the research assistants administered students' Motivation in Quantitative Economics Learning Scale to the students. The research assistants collected the pre-test, marked, recorded and handed them over to the researcher for further use. After that, the experiment commenced. The control group was taught with conventional method with explanation while the experimental group was taught with twodimensional animation instructional technique with students - teacher interaction when the video is paused. The period of teaching in each of the groups was for four weeks. The same topics were used in four intact classes but with different techniques. The topics that were treated in the four weeks are as follows:

Week 1: $\quad$ Concept of Demand

Week2: Concept of Supply

Week 3: Production Possibility Curve

Week 4: $\quad$ Concept of cost and Revenue 
In teaching each of the topics mentioned above using the two-dimensional technique, the teacher adopted the following instructional procedure:

Step 1. Introduction and identification of previous knowledge: The teacher tested the entry behaviour of the students by asking them questions on the basis of what she presented for the day.

Step 2. Explanation of two-dimensional technique: The teacher explained to the students the teaching technique she will use in the classroom. She informed them that there will be a video on the quantitative Economics concepts she will present. She also informed them that they will be attentive to the video to enable them to view and listen to the explanation from the audio. They are also informed to have written materials and pen to write down important ideas and facts from the viewing. She explained to them about students - teacher interaction section where there will be a pause after the viewing; that it is a section the teacher will explain certain points to them and they are free to ask questions for more clarification on what they have viewed.

Step 3. Commencement of the viewing: The teacher switched on the computer and the projector to commence the viewing. The viewing lasted for some minutes. The teacher moves around the classroom to make sure that every student are attentive and watching the viewing. She ensured that the arrangement of the classroom was suitable for every student and they are seeing the projector screen.

Step 4. Students - Teacher interactions: The teacher paused the video in between for students- teacher interaction section to know whether the knowledge is transferred or not. She explained what the students viewed and allow the students to ask questions and made their input on what they have viewed. After that, she allowed the students to write down their notes. The teacher played and replayed the video twice to carry everybody along.

Step 5: Evaluation: After the viewing, the teacher displayed evaluation exercise on each topic and ask students questions. The students answered in various ways. The students that got the best answer were rewarded.

On the other hand, lecture instructional technique was used in teaching the control group. The lesson procedure consists of the following steps:

Step 1: The teacher asked questions to test the students' entering behaviour and introduced the topic.

Step 11: The teacher defined the concepts to the students and explained it to the students with examples. The students listen, asked questions, and took down their notes.

Step 111: The teacher summarised the lesson through repetition of major points arrived in the course of the lesson.

Step 1V: The teacher evaluates the lesson and asked students questions based on what she taught them. Students write down their notes.

After the teaching that lasted for four weeks for the two groups, the research assistants administered the Students Motivation in Quantitative Economics Learning Scale (SMQELS) as post-test. At the end of the post-test, students' scripts were collected by the research assistants, marked, scored, recorded and handed over to the researcher for data analysis. The scores obtained from the groups (experimental and control group) were compared and used to address the research questions and hypotheses. 

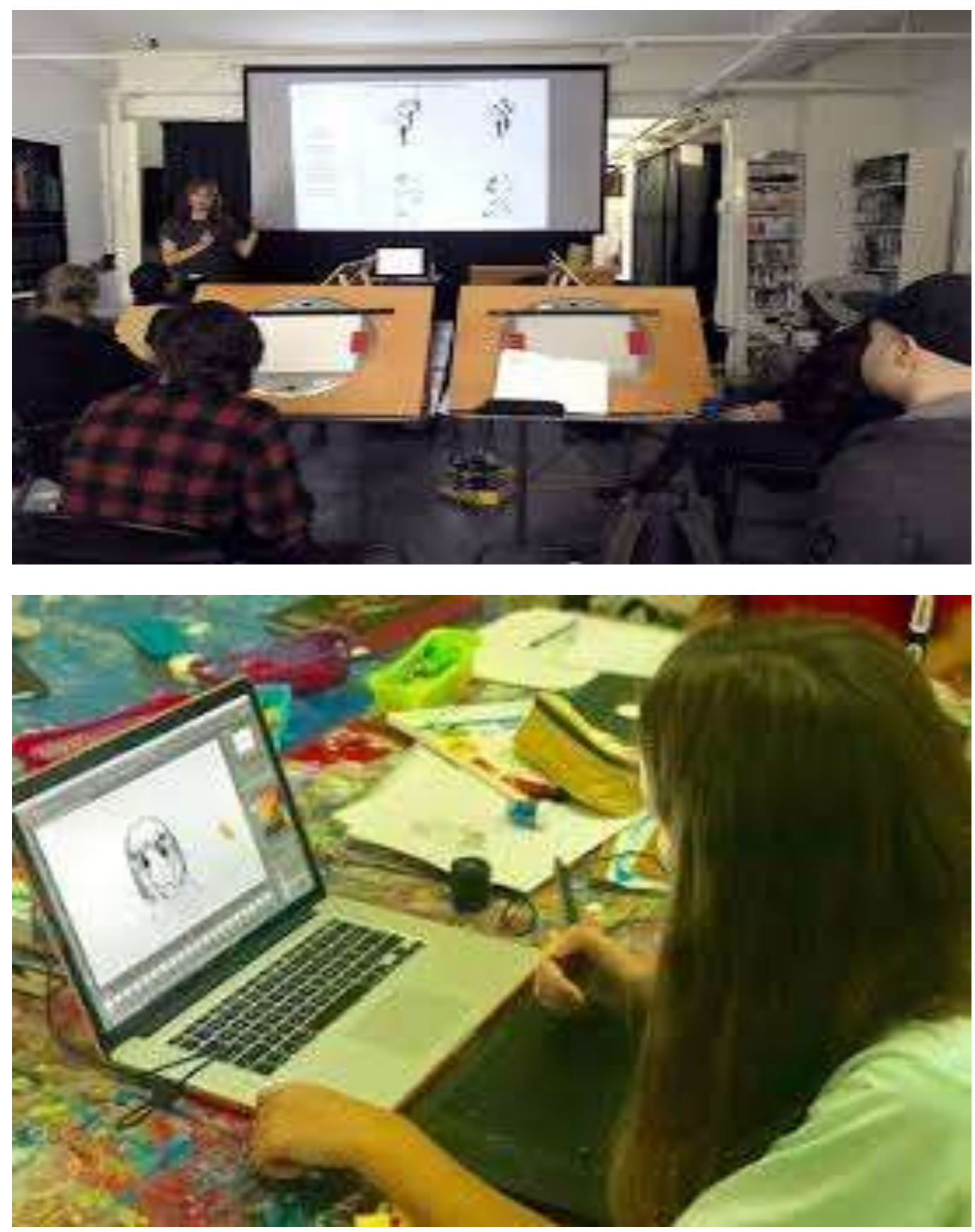

Fig. 3 Class Session with 2D Animation Software

\subsection{DATA ANALYSIS}

The effectiveness of 2D animation technique in enhancing students' motivation in quantitative contents of economics was determined using analysis of covariance (ANCOVA). The effect size of the intervention was reported using Partial Eta squared. The assumption of the homogeneity of variance was determined using Leven's test of equality of variance $(F=1.065, p=.287)$. The analysis was done using statistical package for social sciences version 18.0. 


\section{RESULTS}

Table I. Analysis of covariance of the effect of 2D animation technique on students' motivation in quantitative contents of Economics

\begin{tabular}{|c|c|c|c|c|c|c|c|}
\hline Time & Group & Mean (SD) & $\mathrm{F}$ & $\mathrm{p}$ & $\eta^{2}$ & $\Delta \mathrm{R}^{2}$ & $95 \% \mathrm{CI}$ \\
\hline \multirow{3}{*}{1 Pre-test } & Experimental & $31.54(5.46)$ & \multirow{3}{*}{.001} & \multirow{3}{*}{.975} & \multirow{3}{*}{.000} & \multirow{3}{*}{.000} & \multirow{3}{*}{$23.76,42.28$} \\
\hline & Control & $29.44(12.39)$ & & & & & \\
\hline & Experimental & $68.28(11.82)$ & & & & & \\
\hline 2 Post-test & Control & $42.65(14.72)$ & 93.356 & $<.050$ & .637 & .656 & $40.04,72.61$ \\
\hline \multirow[t]{2}{*}{3 Follow-up } & Experimental & $68.79(5.67)$ & \multirow[t]{2}{*}{89.816} & \multirow[t]{2}{*}{$<.050$} & \multirow[t]{2}{*}{.623} & & \\
\hline & Control & $41.03(13.81)$ & & & & .634 & $39.72,73.37$ \\
\hline
\end{tabular}

Table I reveals that there was no significant difference in the mean motivation ratings of students in the experimental and control groups as measured, $F(1,157)$ $=.001, p=.975, \mathrm{y}^{2}=.000, \Delta \mathrm{R}^{2}=.000$. At the post test and follow-up measures, the effect of $2 \mathrm{D}$ animation technique on students' motivation in quantitative contents of economics was significant, $F(1,157)=93.356, p<.050, \mathrm{y}^{2}=.637, \Delta \mathrm{R}^{2}$ $=.656$; and $F(1,157)=89.816, p<.050, \mathrm{n}^{2}=.623, \Delta \mathrm{R}^{2}=.623$.

The findings further showed that there is no significant interaction effect of time of measures and treatments on students' motivation in quantitative contents of economics contents, $F(1,157)=1.052, p=.099$. This implies that students' motivation in quantitative contents of economics contents as a result of their exposure to 2D animation technique is not affected by the time of measures. Figure 2 shows the graph of interaction of time and treatments.

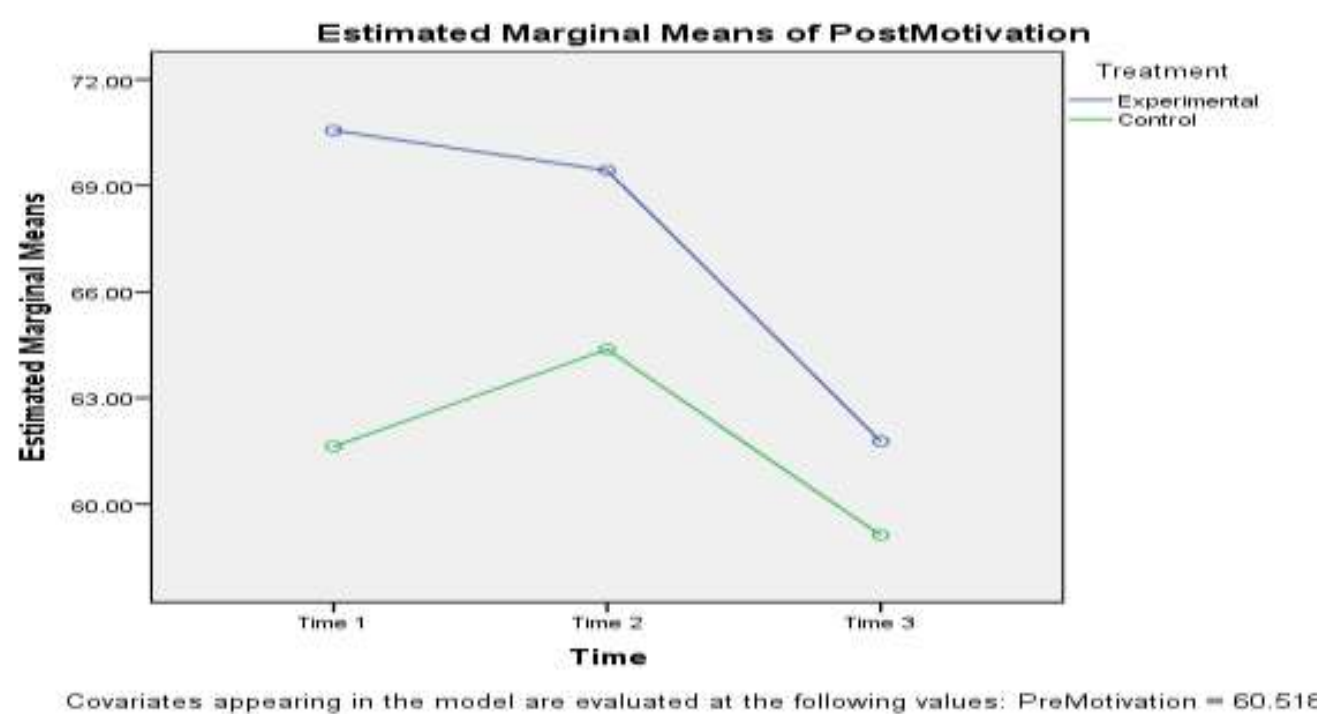

Fig. 3 Interaction Plot of Time of Measure and Treatment

\section{DISCUSSION OF THE FINDINGS}

The finding of this study revealed that students in the experimental group who were taught quantitative Economics concepts using two-dimensional animation technique had a higher post-test mean motivation score than those taught with conventional method with the same secondary schools quantitative Economics concepts. There was high statistically significant difference in the mean scores. Thus, the null hypothesis was rejected which implies that there is a significant difference in the mean motivation scores of students 
taught quantitative Economics concepts in secondary schools using two-dimensional animation technique and those taught with conventional method in favour of those taught using $2 \mathrm{D}$ animation technique.

The finding of this study corroborates with those of [23, 25-27] on the effect of computer animation on students' motivation in related fields of studies such as Biology, Computer course, Student thinking, Science and Technology. For example, [25, 26] in their study on the effect of computer animation on students' motivation in Science, Technology and Computer course found that animation when employed in the teaching and learning process was very efficacious in motivating students' in the classroom. This study has established beyond doubt that it is the same in Economics. [27] showed that students who studied with animation pedagogy movies developed greater motivation to learn science than others who studied science in a traditional way.

Efficacy of 2D animation technique in teaching and learning of quantitative Economics concepts in secondary schools in this technological era can be said to be hope for a better future development as far as instructional delivery and improve achievement is concerned. This is because of its interactive nature. It makes students to be more focus and less distractive and also increases their interest in learning new things every time. It motivates learners to continue their learning outside the classroom with the lesson in a CD form. Hence, there is continuity of learning even after the normal classes due to the motivating capacity and nature of 2D animation technique. The interesting thing in 2D animation technique is that, it makes the abstract concepts to be easier and comprehensible. The implication of this finding is that the increase in motivation of Economics students in Quantitative Economics concepts is attributed to the teaching technique (2D animation) applied.

The result of this study conforms to Cognitive theory of multimedia learning which states that learning becomes effective when it comes from words and pictures than words alone. This implies that words and pictures combine together (such as 2D animation) during learning increase motivation. This theory stipulated that auditory and visual channels are important for processing information. Two-dimensional (2D) technique possesses the characteristics in Mayer's theory that is why it brings students' mind together wherever it is and makes them to be focus on what the teacher will be presenting in the classroom. Motivation enables the students to discover the areas that are necessary to learn in the concepts. When two-dimensional animation technique motivates students during learning process, information gathered are stored in the long term memory. Hence, 2D animation increases the learners' ability to learn more and more. Mathematical figures represented in actual pictures accompanied with verbal process motivate students' interest and enhance quick transfer of knowledge. This technique is found to be effective in teaching quantitative Economics concepts as revealed in this study. Therefore, as the world is revolving around the technological era, there is need to use technological devices like 2D animation video to impact knowledge to the students in secondary schools.

\section{CONCLUSION}

Based on the findings of this study, the research concluded that two-dimensional animation technique had a strong significant effect on students' motivation in Secondary Schools Quantitative Economics concepts. This means that two-dimensional animation technique proved to be effective in enhancing students' motivation in Quantitative Economics concepts in Secondary Schools. The educational implication of this finding is that full integration of the use of $2 \mathrm{D}$ animation technique in classroom instructional delivery will lead to enhanced motivation of students in quantitative contents of economics. It was therefore recommended that;

1. Since the world is in technological era, teachers should be encouraged to use twodimensional technique in teaching and learning process in order to motivate 
students in abstract concepts like quantitative Economics concepts which is one of their weaknesses as it was reported in Chief Examiner's Report.

2. Students should value the opportunity offered by animation technique which engages them in independent study both within and outside the classroom so as to comprehend abstract concepts like quantitative Economics concepts.

3. Curriculum planners like NERDC should introduce and design learning packages like two-dimensional animation technique in Economics curriculum and make it compulsory for Economics teachers to use it in the classroom during instruction in order to bridge the incessant poor performance of Economics students in secondary schools.

\section{REFERENCES}

[1] West African Examination Council. 2012. Chief Examiner's Report. Abuja: West African Examination Council.

[2] West African Examination Council. 2013. Chief Examiner's Report. AbujaWest African Examination Coucil.

[3] West African Examination Council. 2015. Chief Examiner's Report. Abuja: West African Examination Council.

[4] West African Examination Council. 2016. Chief Examiner's Report. Abuja: West African Examination Council.

[5] West African Examination Council. 2017. Chief Examiner's Report. Abuja: West African Examination Council.

[6] West African Examination Council. 2018. Chief Examiner's Report. Abuja: West African Examination Council.

[7] Frenzel, A. C., Goetz, T., Pekrun, R.,Watt, H.M. 2010. Development of Mathematics interest in Adolescence: Influences of Gender, Family and School context. Journal of Research on Adolescence, 20(2), 507-537. doi:10.1111/j.1532-7795-2010.00645.x.

[8] Leder, G. 2015. Gender and mathematics Education Revisited. The proceedings of the 12th International Congress on Mathematical Education (pp. 145-170). Switzerland: Springer, Cham.

[9] Stoehr, K. 2016. Mathematics Anxiety. Journal of Teacher Education, 68(1), 69-84.

[10] Ejimonye, J.C., Eneogu, N.D., Ugwuanyi, C.S. 2017. Analysis of student's perception of Mathematical contents of Economics that are difficult for sustainable teaching and learning of Economics in secondary schools in Enugu Urban. International Journal of studies

[11] Adu, E. 2012. Two Problem Based learning Strategies for Teaching Economics. Germany: Lambert Academic Publishing.

[12] Kim. E. 2016. Three Reasons why some Teachers STILL aren't embracing the use of Technology in the classroom [web log post]: Retrieved from https://blog.esparklearning.com/

[13] Fitzgerald, R. 2018. What is 3D animation? College of digital art and animation.www.cgspectrum.edu.au. retrieved $16^{\text {th }}$ of September, 2019.

[14] Wu, C., Chiang, M. 2013. Effectiveness of applying 2D static depictions and 3D animations to Orthographic view learning in graphical course. Computers \& Education, 1, 28 - 42.

[15] Dermitzaki, I, Stavroussi, P, Vavouggls, D \& Kotsis. (2013). Adaptation of the Students' Motivation towards Science Learning Questionnaire in the Greek Language. European Journal of Psyschology of Education, 28(3) 747 - 766 .

[16] Gbollie, C., Keamu, H.P. 2017. Student academic performance: The role of motivation, strategies and perceived factors hindering Liberian Junior and Senior high school Students learning. Journal of Educational Research International, 1(1), 1-11.

[17] Aydin, G. 2017. Personal factors predicting college students success. Eurasian Journal of Educational Research, 69, 93 -112.

[18] Alivernini, F, Cavicchiolo, E, Palmerio, L., Girelli, L. 2015. Representations of study and students academic motivation. Journal of Procedia-social and Behavioural Sciences, 205, 302 -305.

[19] Cook, D. A., Artino, A.R. 2016. Motivation to learn: an overview of contemporary theories. Journal of Msdical Education, 50 (10), 997 - 1014.

[20] Huitt, W. 2011, February 11. Motivation to learn: an overview. Educational Psychology interactive. Valdosta, GA, Valdosta, United States.

[21] Saeed, S., Zyngier, D. 2012. How motivation influences student engagenet: A qualitative case study. Journal of Education and Learning, 1(2), 1927 - 5269.

[22] Koca, F. 2016. Motivation to learn and teacher-student relationship. Journal of International Education and Leadership, 6(2), 2161 - 7252. 
[23] Yisa, N. C., Ojiaku, F.C. 2016. Effectiveness of Computer Animation on a Progressive Learning Achievement of Secondary School Biology Students in Niger State, Nigeria. . International Journal of Education and Evaluation , 4 (2), 2473 - 2489.

[24] Kwasu, I.A., Ema, E. 2015. Effectiveness of Animated Instructional Resource form Learning Facilitation among Secondary School Student in Bauchi Nigeria . Journal of Education and Practice , $12,2222-1735$.

[25] Rosen, Y. 2009. The effects of an animation-based on-line learning environment on transfer of knowledge and on motivation for science and technology learning . Journal of Educational Computing Research, 40(4), $451-467$.

[26] Ozdemir, O., Oner,I.E. 2015. The Effects of Simulations and Animations on Students' Motivation in a Computer Course . Participatory Educational Research (PER) , 2, 53 -59.

[27] Barak, m, Askar, T., Dori, Y. 2011. Learning science via animated movies: Its effect on students Thinking and motivation. Journal of computer \& Education, 1, 839 - 846. 
International Journal of Future Generation Communication and Networking Vol. 13, No. 1 (2020) 